\title{
Search of effective IRAP markers for sakura genotyping*
}

\author{
Ilya Stepanov **, Ilnur Balapanov, and Anna Drygina \\ Federal State Budget Scientific Institution «North Caucasian Federal Scientific Center of \\ Horticulture, Viticulture, Wine-making», 39 str. 40 Let Pobedy, Krasnodar, 350901, Russia
}

\begin{abstract}
The aim of this study is to find and use effective IRAP markers for DNA genotyping of representatives of sakura species (ornamental cherries). The work demonstrates the results of testing ISSR markers on the genotypes of the species $P$. serrulata. Also, based on the testing data, the selection of effective IRAP markers was carried out. The selected IRAP markers were used in the genetic analysis of 12 sakura genotypes.
\end{abstract}

\section{Introduction}

The practice of using multilocus markers as tools for DNA certification has been widely introduced into genetic research. The demand for multilocus DNA genotyping methods is due, in particular, to the ability to use this method to quickly and efficiently evaluate samples. Among the most important from the wide variety of multiloci DNA markers are IRAP markers. IRAP marker polymorphism nature consists in the variability of the genome regions localized between the insertion sites of a the same type retrotransposons [1-2]. A lot of research in the field of applied genetics have been carried out proving the effectiveness of the IRAP analysis method [3-5]. IRAP markers are genomic regions bounded by retrotransposon insertions on both sides. [6-7]. In the course of IRAP labeling, one variant of the primer is used in the PCR mixture, which is complementary to the termination of the particular retrotransposons LTR region [8]. In this connection, the IRAP sequence in PCR acts as a forward and reverse primer, flanking the target DNA fragments from both sides [9]. Thus, IRAP genotyping makes it possible to obtain an informative DNA fingerprint for each genotype, which allows genetic identification and assessment of kinship [10]. In turn, the IRAP genotyping method is easy to implement and not resource-demanding. The above-mentioned features of this method make it a convenient approach in genetic studies of cultures at the initial stage [11-12].

Among the first works on the Prunus genotyping representatives using retrotransposon markers, two main ones actually carried out by $P$. mume and $P$. domestica can be noted. In the first work, 84 japanese plum specimens were successfully genotyped with IRAP and REMAP markers; the results were published in 2011 (Prunus mume Sieb. Et Zucc.) [13].

\footnotetext{
* The study was carried out with the financial support of the Russian Foundation for Basic Research and the Krasnodar Territory Administration within the framework of the scientific project No. 19-44233011 r_mol_a

${ }^{* *}$ Corresponding author: ivstepanof@gmail.com
} 
For this work, was used markers based on information about the LTR sequences of previously sequenced retrotransposons. When creating REMAP markers for the selection of a primer complementary to the tandem repeats found in the EST of apricot and japanese plum. The second work, published in 2013, consisted of an 12 European domestic plum varieties IRAP analysis to assess their relationship [14]. The work involved two IRAP markers based on the sequences of the Cassandra retrotranspazone detected in the $P$. domestica genome. The markers developed were designated Cass1 and Cass2.

In connection with the relevance of using IRAP as a tool for the representatives genotype of the genus Prunus, the goal was created to search and test effective IRAP markers for genetic analysis of sakura varieties.

This work presents the results of testing 5 IRAP markers on 2 P. serrulats genotypes with subsequent selection of the most effective markers. The selected markers were used in genotyping 12 various origin samples. The data obtained made it possible to obtain information about the genetic relationship of the studied samples and about the originality of the IRAP markers used.

\section{Methods}

Extraction of the DNA from young leaves was carried out by modified CTAB protocol. For the study, 12 genotypes of cherry blossoms were selected, are shown in Table 1.

Table 1. Cherry blossom samples selected for genotyping.

\begin{tabular}{|l|l|l|}
\hline № & Name & Species affiliation \\
\hline 1 & Rexii & P. cerasus rexii \\
\hline 2 & Royal Burgundy & P. serrulata (Lindl.) \\
\hline 3 & Shirofugen & P. serrulata (Lindl.) \\
\hline 4 & Kanzan & P. serrulata (Lindl.) \\
\hline 5 & Yamasakura & P. serrulata jamasakura (Lindl.) \\
\hline 6 & Shiatsu & P. serrulata (Lindl.) \\
\hline 7 & Kiku-shidare & P. lannesiana Carreiere \\
\hline 8 & P. incisa 1 & P. incisa \\
\hline 9 & Utreneje Oblako & P. incisa $\times$ P. avium \\
\hline 10 & BE-43-1 & $\begin{array}{l}\text { P.cerasus } \times \text { И 43 } \text { (P. avium } \times \text { P. } \\
\text { lannesiana) }\end{array}$ \\
\hline 11 & BE-43-2 & $\begin{array}{l}\text { P.cerasus } \times \text { U 43 (P. avium } \times \text { P. } \\
\text { lannesiana) }\end{array}$ \\
\hline 12 & Vesennyi Kapriz & P. cerasus $\times$ P. lannesiana \\
\hline
\end{tabular}

IRAP markers were selected from the literature [13, 14, 15]. IRAP PCR was performed under the following conditions: $3 \mathrm{~min}$. initial denaturation at $95^{\circ} \mathrm{C}$; further 35 cycles: denaturation for $35 \mathrm{~s}$. at a temperature of $95^{\circ} \mathrm{C}$, then annealing the primers for $1 \mathrm{~min}$. at 55 ${ }^{\circ} \mathrm{C}$, then elongation for $1.5 \mathrm{~min}$. at $72^{\circ} \mathrm{C}$, and final elongation at $72^{\circ} \mathrm{C}$ for $5 \mathrm{~min}$. Concentrations of the components used in the reaction mixture: 1 buffer for Taq DNA polymerase, dNTP $(2.5 \mathrm{mM}), 1$ unit. Act. Taq DNA polymerase, primer $(0.64 \mu \mathrm{M})$ and $40-$ $50 \mathrm{ng}$ total DNA per reaction. In order to test IRAP markers, electrophoresis of the obtained PCR products was carried out at a voltage of $120 \mathrm{~V}$ in an agarose gel with a concentration of $2 \%$, stained with ethidium bromide. For genotyping of samples using IRAP markers, 
electrophoresis of PCR products was carried out at a voltage of $60 \mathrm{~V}$ in a $3.5 \%$ agarose gel stained with ethidium bromide. DNA visualization with subsequent photographic fixation was carried out in ultraviolet. The parameters effective allele number, Shannon diversity index, and diversity index were calculated using the Microsoft Office Excel 2007 GenAlEx 6.503 macro. Principal coordinate analysis (PCOA) was performed using the Past 2.17a software.

\section{Results and discussion}

In this study, we tested 5 IRAP markers on the sakura genotype in order to determine the most effective markers for the subsequent genotyping of this culture and its hybrids (Figure 1). The approbation of IRAP markers showed that 4 out of 5 markers produced amplification products during PCR. For one marker no amplified DNA fragments were detected in the marker after visualization of electrophoresis results. Further use of the marker within this taxon is not promising.

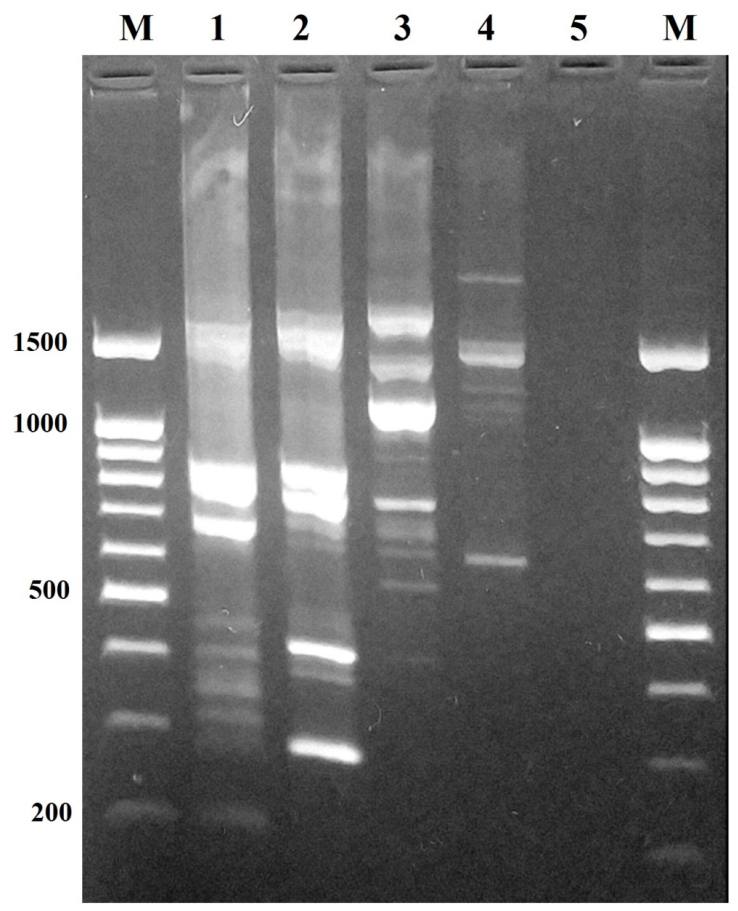

Fig. 1. Results of IRAP markers aprobation.

Legend: M - molecular weight marker; 1) Cass 1; 2) Cass2 3) LTR3 4) LTR23 5) IRAP TDK 2F.

Thus, based on the results of testing, the markers were divided into 3 groups: from 3 to 1 in the gradation of improving the quality of amplification products. The IRAP TDK $2 \mathrm{~F}$ marker, which did not give PCR products during genotyping of the cherry blossom sample, was assigned to group 3. The second group includes markers previously tested on the Chinese plum, LTR 3 and LTR 23. Both markers gave clearly distinguishable DNA fragments on the electrophoretogram. The number of DNA fragments obtained during amplification varied from 7 for the LTR 23 marker, to 10 for the LTR 3 marker. The largest 
number of DNA fragments was observed in the Cass 1 and Cass 2 markers included in the first group, complementary to the LTR sequences of the Cassandra retrotransposon. These markers have previously been shown to be effective on various Prunus species. The number of DNA fragments obtained varied from 12 for the Cass 2 marker to 13 for Cass 1.

Based on the results of testing IRAP markers on the sakura genotype, markers from the first group were selected for further genotyping of this culture, which gave the maximum number of DNA fragments during amplification. Our genotyping with the use of Cass 1 and Cass 2 was carried out on 12 samples of cherry blossoms: 5 samples refer to the species $P$. serrulata, one representative for the species $P$. lannesiana Carreiere, $P$. incise, $P$. cerasus rexii, and 4 interspecific hybrids of cherry trees.

Based on the results of genotyping, DNA fragments were counted using the obtained fingerprins of the analyzed varieties. On a sample of 12 sakura genotypes, 28 polymorphic DNA fragments were identified in Cass 1 and 24 in Cass 2.

Using GenAleX software, a number of marker parameters were assessed reflecting the degree of their polymorphism: effective number of alleles (Ne), Shannon's diversity index (I), and diversity index (h) (Table 2). For all three indicators, the parameters of Cass 1 slightly exceed Cass 2. In general, we can say that both markers have sufficient polymorphism for their use in genotyping cherry varieties and forms, as well as their hybrids, at the same time, the Cass 2 marker is slightly inferior to the Cass marker 1 on polymorphism.

Table 2. Marekers Cass1 and Cass2 parmeters.

\begin{tabular}{|l|l|l|l|}
\hline Markers & Ne & I & h \\
\hline Cass 1 & 1,588 & 0,522 & 0,347 \\
\hline Cass 2 & 1,477 & 0,460 & 0,296 \\
\hline
\end{tabular}

The performed genotyping made it possible to obtain data allowing to determine the genetic relationship of the studied samples (Fig. 2).

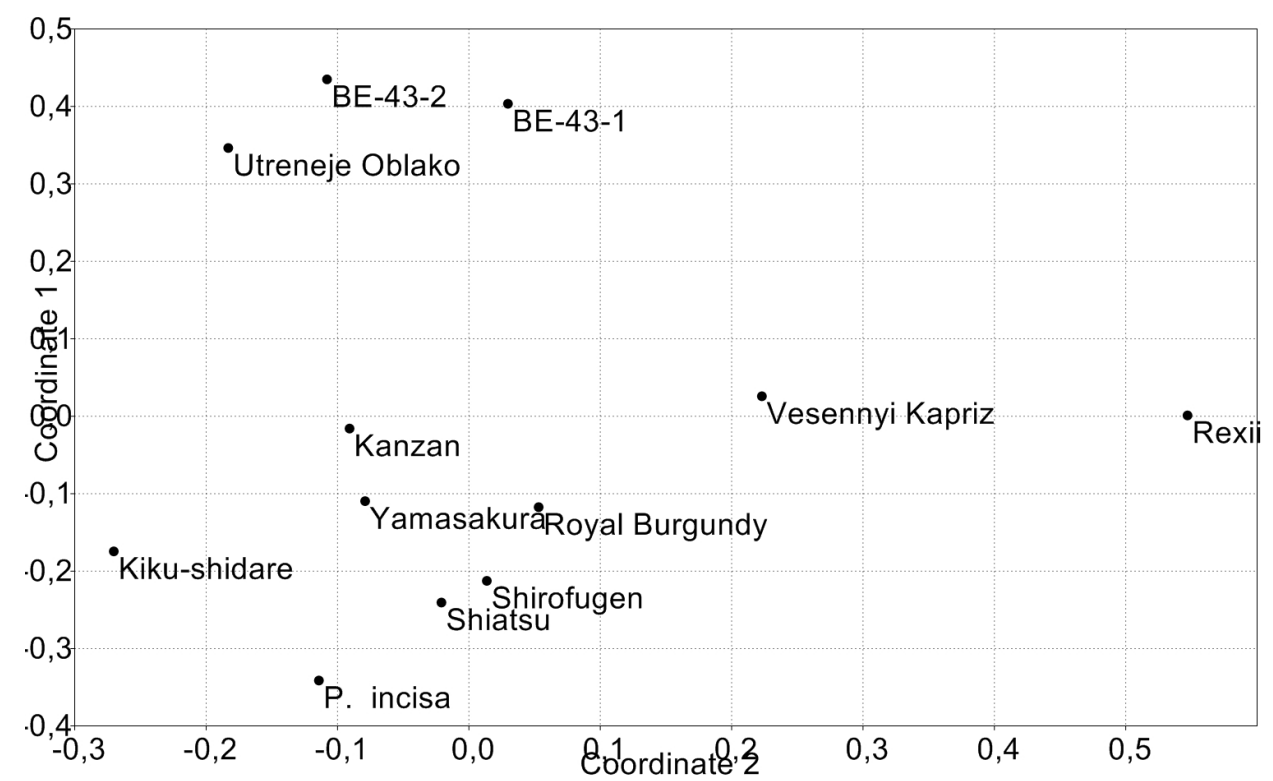

Fig. 2. PCoA plot of genotyping results for 12 cherry blossom samples. 
The information obtained during PCOA makes it possible to distinguish two groups of samples. The first group includes P. serrulata varieties. The second group includes three hybrids P.cerasus x I 43 ( $P$. avium $x$ P. lannesiana). The outgroup is the $P$. cerasus rexii genotype. Representatives of two species $P$. lannesiana Carreiere, $P$. incise are close to $P$. serrulata. The Spring Caprice hybrid occupies an intermediate position between Rexii and the $P$. serrulata cultivar group. What generally fits into the taxonomic concept of the relationship of species of ornamental cherries.

\section{Conclusion}

The carried out research work allowed to identify effective IRAP markers for genotyping of decorative cherries - sakura. In the course of testing IRAP markers, Cass 1 and Cass 2 were selected for genotyping cherry tree samples. Genotyping of 12 cherry tree samples using two selected markers demonstrated their effectiveness as tools for DNA profiling. The clustering results obtained from the genotyping data for cherry blossoms are consistent with information about their origin. This allows us to assert that the use of these IRAP markers is promising in works aimed at establishing the relationship of genotypes within the studied taxon.

The study was carried out with the financial support of the Russian Foundation for Basic Research and the Krasnodar Territory Administration within the framework of the scientific project No. 19-44233011 r_mol_a.

\section{References}

1. C. Guan, S. Chachar, P. Zhang, C. Hu, R. Wang, Y. Yang, Hortic. Plant J., 6(2), 71-80 (2020) https://doi.org/10.1016/j.hpj.2019.12.005

2. L Alikhani, M.-S. Rahmani, N Shabanian, H. Badakhshan, A. Khadivi-Khub, Gene, 552(1), 176-183 (2014) https://doi.org/10.1016/j.gene.2014.09.034

3. S. V. Boronnikova, R. N. Kalendar, Russ. J. Genet, 46, 36-42 (2010) https://doi.org/10.1134/S1022795410010060

4. A. Cheraghi, F. Rahmani, A. Hassanzadeh-Ghorttapeh, Mol. Biol. Res. Commun., 7(3), 125-132 (2018) http://doi.org/10.22099/mbrc.2018.29924.1327

5. D. Strioto, B. Kuhn, W. Nagata, G. Marinelli, S. Oliveira-Collet, C. Mangolin, M. Machado, Plant Genetic Resources: Characterisation and Utilisation, 17(3) 272-279 (2019) https://doi.org/10.1017/S1479262119000029

6. L. Yuan, Q. Zhang. D. Guo, Z. Luo, Sci. Hortic., 137(1), 75-80 (2012) https://doi.org/10.1016/j.scienta.2012.01.027

7. M. Shaidai, M. Riazifar, A. Hoordadian, O. Alishah, Plant Gene, 14, 12-19 (2018) https://doi.org/10.1016/j.plgene.2018.04.001

8. P. Pandotra, A. P. Gupta, S. Khan, G. Ram, S. Gupta, Sci. Hortic., 194, 201-207 (2015) https://doi.org/10.1016/j.scienta.2015.08.011

9. S. Singh, P.S. Nandha, J. Singh, Crop J., 5(4), 296-304 (2017) https://doi.org/10.1016/j.cj.2017.01.003

10. A. Noroozisharaf, A. Hatamzadeh, H. S. Lahiji, D. Bakhshi, Sci. Hortic., 190, 173-178 (2015) https://doi.org/10.1016/j.scienta.2015.04.028

11. M. K. Biswas, Q. Xu, X.-X. Deng, Sci. Hortic., 124(2), 254-261 (2010) https://doi.org/10.1016/j.scienta.2009.12.013 
12. B. Abdollahi Mandoulakani, S. Rahmanpour, S. Shaaf, S. Gholamzadeh Khoei, M. Rastgou, R. Rafezi, S. Afr. J. Bot., 100, 141-147 (2015) https://doi.org/10.1016/j.sajb.2015.05.027

13. S. Yuying, D. Xiajun, W. Fei, C. Binhua, G. Zhihong, Z. Zhen, Sci. Hortic., 132(1), 50-58 (2011) https://doi.org/10.1016/j.scienta.2011.10.005

14. S. Senkova, J. Žiarovská, M. Bežo, V. Štefúnová, K. Ražná, Bioscience Research, 10(1), 01-07 (2013) https://www.isisn.org/BR\%2010\%20(1)\%202013/0107\%2010(1)\%202013\%20BR-1001.pdf

15. D. Jawdat, H. Al-Faoury, Z. Ayyoubi, B. Al-Safdi, Biologia 65(5), 796-804 (2010) http://doi.org/10.2478/s11756-010-0086-7 